UDC 631:11:502.131

JEL Classification: Q13, Q56, M14

DOI: https: //doi.org/10.32317/2221-1055.201909052

M.M. IHNATENKO, doctor of economic sciences, associate professor (docent)

\title{
Ecological components and instruments of implementation of social responsibility to agrobusiness enterprises
}

\begin{abstract}
The purpose of the article is to substantiate the selection and implementation of tools and means of enhancing the social responsibility of subjects of agribusiness environmental component, including on basis of prudent use of genetically modified organisms (GMOs) and development of manufacture of organic products related to food security in general.

Research methods. The methodological basis of the study is the position of modern economic theory, economics of agribusiness enterprises, the concept of social responsibility, rational use of nature and sustainable development. The article uses general scientific methods of scientific knowledge - dialectical, historical, monographic (in determining the trends of agricultural production, nature management, its ecology and social responsibility for them); system-structural analysis and synthesis (when analysing and structuring environmental problems, developing a common strategy and tactics for solving them by means of social responsibility), as well as statistical-economic and socio-environmental studies (when setting quantitative indicators and indicators of environmental management and ecology in process of agrarian production, establishment of causal relationships between them and their measurement), expert assessments, sociological survey (in substantiating the prospects of solution environmental problems within the concept of social responsibility in the absence of statistical sources of calculations and forecasts).
\end{abstract}

Research results. The article identifies features, problems and made an assessment of ecological efficiency and greening of agrarian production, incl. use of GMOs and their consequences. The necessity of social responsibility of agribusiness enterprises for ecological consequences of activity is substantiated. Its functions, principles, tools and mechanisms in solving environmental problems are defined. Advanced agricultural business entities are increasingly paying attention to reducing the negative impact of their activities on the environment. The value of such initiatives in the area of environmental responsibility is emphasized: reduction of energy and resource intensity of production; increasing the amount of waste used or disposed of by the enterprise; development and implementation of strategic programs of environmental activities, first of all, reclamation; implementation of international standards of environmental responsibility; environmental monitoring of technology, agricultural raw materials and food, and others. This indicates the gradual expansion of the priorities of the environmental component in the system of social responsibility of domestic enterprises of the agricultural sector of the economy. However, even at the leading domestic agricultural enterprises, its level does not reach international standards. It needs further development, especially at the level of large agricultural holdings and transnational agricultural corporations.

Elements of scientific novelty. For the first time, within the concept of social responsibility, the environmental component was clarified and the means of its enhancement were determined in the form of prudent use of GMOs, organic production, introduction of environmentally oriented management. The importance of using the concept of social responsibility is emphasized. After all, it ensures conscious greening of agriculture at the level of all participants in the production process.

Practical significance. The results and conclusions obtained in the article can be used in training and retraining of executives, specialists, owners of agribusiness enterprises, in their economic activities. It is advisable to introduce them into the work of regional authorities, rural communities, public organizations. Tabl.: 2. Refs.: 22.

Keywords: agrarian enterprises; environmental problems; organic production; genetically modified organisms; social responsibility; tools4 management.

Ihnatenko Mykola Mykolaiovych - doctor of economic sciences, associate professor (docent), head of the economics department, Pereiaslav-Khmelnytskyi Hryhorii Skovoroda State Pedagogical University (30, Sukhomlynskoho st., Pereiaslav-Khmelnytskyi, Kyiv reg.)

E-mail: professorignatenko@ukr.net

ORCID iD https://orcid.org/0000-0002-5713-7951

Scientific problem. The modern era requires the people of Ukraine to solve the problems of building civil society, reform the

(C) M.M. Ihnatenko, 2019 economy on the basis of digitization and comprehensive intensification of production, accelerate scientific and technological progress, structural restructuring of the entire economic complex, forms of management, organization and stimulation of labor. The Scientific 
and Technical Revolution (STR), which is taking place in all developed countries of the world, is complex, dialectically contradictory. Along with the positive results, the negative effects of the STR are clearly traced. The list of such, undoubtedly, should include the growing technogenic impact of civilization on the environment, life and reproduction of the population.

The country has objectively created a situation where the economy cannot successfully grow on an extensive basis by attracting more and more natural and labor resources. This is due to both the natural exhaustion of the explored minerals, increasing difficulties in their extraction and processing, reduced fertility of soils that lead to threatening pollution and changes in the environment, as well as unfavorable demographic processes that do not allow for significant development. The problems of economic development in general and the economic entities of the agrarian sphere in particular are directly related to environmental and demographic problems and can only be addressed if this dialectical relationship is taken into account.

The challenge for the protection of nature and the rational use of its resources in the process of agricultural production is urgently confronted with Ukrainian society, because the normal state of the environment is a necessary condition for its development as a social and production-economic system. It should be borne in mind that scientific and technological progress is not only the basis of economic development, but also a necessary means of solving environmental problems of protecting the environment from pollution, depletion of resources, providing favorable conditions for work and rest of man.

Addressing the economic problems of agrarian -economic entities requires a comprehensive approach that provides for a system of measures for the protection of nature and the rational use of its resources. It is about strengthening the control over nature management; implementation of strict regime of saving of raw materials, fuel, materials; rational use of natural conditions and resources of production; introduction of low-waste and non-waste, resource-saving technologies. Of particular importance is the use of automated systems for production, management, monitoring and control of the environment.
Modern productivity growth is driven by the widespread use of fundamentally new types of technology and technology. It allows not only to successfully solve environmental and economic problems, but also to neutralize the negative impact of the demographic factor on the pace of progressive development of society. Therefore, it is important to justify the environmental component in the system of social responsibility of the entities of the agrarian sphere.

Analysis of recent research and publications. Problems of rational use of nature, greening of production are constantly in the focus of attention of foreign and domestic scientists and practitioners. Numerous publications, including the fundamental works of T. Kniazeva [10], Yu. Lupenko [12], P. Sabluk [18], M. Khvesyk [21], O. Shpykuliak [22], testify to this. Organic production development is devoted to articles by L. Marmul [2] and N. Novak [4]. Issues of introduction of genetically modified organisms, food security are covered in the works of M. Malika [22], O. Reznikova [15]. Particular attention was paid to the problems of greening of agricultural production R. Bezus [7], N. Zinovchuk, A. Malynovskyi [13], O. Prutska [14], O. Popova, A. Sokhnych [19], A. Tretiak, V. Trehobchuk, M. Fedorov and more.

However, the digitization or digitization of all activities in the agrarian sphere on the one hand, and the enhancement of the social orientation of agribusiness on the other, as observed in the current economic environment, require the development of new approaches and new solutions to the environmental problems of agriculture and rural areas. The concept of social responsibility fully meets these requirements. The monographs of D. Baiura, O. Hrishnova [8], A. Kolota, D. Ushakov, S. Kuchyn [3] are devoted to fundamental developments concerning its content, factors, processes, directions. However, justification of tools and methods for solving environmental problems by means of social responsibility requires intensive development.

The purpose of the article is to substantiate the selection and implementation of tools and means of enhancing the social responsibility of subjects of agribusiness environmental component, including on basis of prudent use of genetically modified organisms and development of manufacture of organic products related to food security in general. 
Research methodology. The methodological basis of the study is the position of modern economic theory, economics of agribusiness enterprises, the concept of social responsibility, rational use of nature and sustainable development. The article uses general scientific methods of scientific knowledge - dialectical, historical, monographic (in determining the trends of agricultural production, nature management, its ecology and social responsibility for them); system-structural analysis and synthesis (when analyzing and structuring environmental problems, developing a common strategy and tactics for solving them by means of social responsibility), as well as statistical-economic and socio-environmental studies (when setting quantitative indicators and indicators of environmental management and ecology in process of agrarian production, establishment of causal relationships between them and their measurement), expert assessments, sociological survey (in substantiating the prospects of solution environmental problems within the concept of social responsibility in the absence of statistical sources of calculations and forecasts).

Research results. The development of economic entities in the domestic agrarian economy, their integration into the system of international relations require the setting of stringent requirements for the ecological security of food production and its impact on the environment. In addition, the use of new technologies, the use of synthetic additives and genetically modified organisms in foods place increased demands on food safety and management of its achievement.

One of the components of corporate social responsibility is environmental responsibility, which provides for the protection of workers' health in the workplace, preservation and restoration of a favorable natural environment [13, p. 84]. In the case of the agrarian sphere, it is also about the rational use of agrarian resources, environmentally friendly production technology and clean food. The greening of agrarian production and the activities of agrarian business entities as a component of social responsibility or corporate social responsibility (CSR) means an even broader concept. It is not only compliance with environmental legislation and regulations, but also, the responsibility of enterprises to the present and future generations for environmental protection, which is manifested in the rational use of nature, eco- nomical production and consumption and other actions aimed at improving the environmental situation, living conditions and quality of life of the population.

The essence of environmental responsibility of economic entities of the agrarian sphere is manifested through three main functions: stimulating, compensatory and preventive, and consists in maintaining a stable balance of economic and environmental interests in the process of economic activity based on the prevention, reduction and absence of environmental losses in the natural environment [3, p. 298]. Such a question requires the integrated implementation of the values of environmental responsibility in the practice of management and in the corporate culture of agricultural enterprises and corporations.

Most Ukrainian businesses recognize only legal environmental liability, and many organizations allow it to be breached for economic gain. At the same time, the number of enterprises whose management is aware of the severity of the global environmental crisis and is trying to contribute to the environment is increasing every year. The environmental component of social responsibility is one of the key requirements for the entry of domestic agrarian business entities into the world food market, where the environmental friendliness of goods and services is one of the most important competitive advantages. Export-oriented Ukrainian agricultural companies already produce agricultural and food products that meet European environmental standards, which are much more stringent than domestic ones.

Social conflicts arising around environmental problems associated with the activities of economic entities of the agrarian sphere, especially agrarian holdings, transnational industrial corporations, are largely caused by the lack of adequate information about enterprises and their production and technological processes implemented [20, p. 8]. Therefore, in the creation and dissemination of reliable environmental information about them, their owners, managers and employees should be primarily interested.

To this end, it is advisable to publish annually in Ukraine, for example, environmental ratings (environmental cost ratings), which are an objective comparison of different enterprises, industries, regions regarding the environmental impact of food production, food quality and the impact of their ingre- 
dients. on the human body. The system of environmental cost ratings, in particular, is intended to inform the public, public authorities and businesses about the situation in the sphere of impact on nature and objective monitoring of changes. Estimates are made on the basis of open information on volumes of use of natural resources, pollution of land, water and air, generation of waste, areas of land devoid of natural vegetation, territories of radiation pollution, etc. [9, p. 393].

The difficult environmental situation in Ukraine is evidenced by the fact that in the ranking of countries on the environmental sustainability index, developed by the Center for Environmental Law and Policy of Yale University, in 2017, Ukraine ranked 102 among 132 countries (Table 1 ).

Table 1. Ecological Sustainability Index of the World, 2017

\begin{tabular}{|c|l|c|l|}
\hline Rating & \multicolumn{1}{|c|}{ Country } & Rating & \multicolumn{1}{|c|}{ Country } \\
\hline 1 & Switzerland & 95 & Congo \\
\hline 2 & Latvia & 96 & Trinidad and Tobago \\
\hline 3 & Norway & 97 & Macedonia \\
\hline 4 & Luxembourg & 98 & Senegal \\
\hline 5 & Costa Rica & 99 & Tunisia \\
\hline 6 & France & 100 & Qatar \\
\hline 7 & Austria & 101 & Kyrgyzstan \\
\hline 8 & Italy & 102 & Ukraine \\
\hline 9 & United Kingdom & 103 & Serbia \\
\hline 9 & Sweden & 104 & Sudan \\
\hline 11 & Germany & 105 & Morocco \\
\hline 12 & Slovakia & 106 & Russian Federation \\
\hline 13 & lceland & 107 & Mongolia \\
\hline 14 & New Zealand & 108 & Moldova \\
\hline 15 & Albania & 109 & Turkey \\
\hline
\end{tabular}

Source: Environmental Performance Index, 2018.

The Environmental Sustainability Index reflects the country's achievements in terms of ecology and natural resource management. If we consider the environmental sustainability index of Ukraine in 2012 by separate indicators, the situation in such components as "Air" (impact on ecosystems or beyond) and "Ensuring ecosystem activity" (Table 2 ) is particularly difficult. With Poland, ranked 22nd, with its

natural resource potential and cultural and historical development conditions, Ukraine is far behind in ensuring environmental sustainability from European countries. This demonstrates the irresponsible attitude to the environment in Ukraine at all levels of management and management, as well as the existing reserves for its improvement.

\section{Table 2. Comparison of the Index and the Indicators of Environmental Sustainability of Ukraine and Poland, 2017}

\begin{tabular}{|l|c|c|c|c|}
\hline \multicolumn{1}{|c|}{ Name of indicator } & \multicolumn{2}{c|}{ Ukraine } & \multicolumn{2}{c|}{ Poland } \\
\cline { 2 - 5 } & Value & Rating & Value & Rating \\
\hline Environmental sustainability index & 46,3 & 102 & 63,5 & 22 \\
\hline Environmental Impact on Health & 72,0 & 61 & 89,2 & 35 \\
\hline Air (impact on human health) & 69,2 & 62 & 100 & 1 \\
\hline Environmental causes of morbidity & 75,4 & 60 & 91,4 & 28 \\
\hline Water (impact on human health) & 68,0 & 53 & 74,0 & 44 \\
\hline Maintenance of ecosystems & 35,3 & 115 & 52,4 & 52 \\
\hline Agriculture & 45,2 & 87 & 48,6 & 78 \\
\hline Air (impact beyond ecosystems) & 18,8 & 112 & 25,4 & 102 \\
\hline Biodiversity and habitat & 46,4 & 88 & 98,8 & 9 \\
\hline Climate change & 25,1 & 107 & 25,9 & 106 \\
\hline Fish stocks & 19,4 & 82 & 27,6 & 53 \\
\hline Forests & 88,9 & 47 & 91,5 & 42 \\
\hline Water (impact beyond ecosystems) & 18,0 & 94 & 32,8 & 61 \\
\hline
\end{tabular}

Source: Environmental Performance Index, 2018. 
Even in agricultural production, domestic economic entities are inferior to Poland in terms of environmental performance. The environmental situation in Ukraine has a negative impact not only on the health of the population, but also on the life of ecosystems. The complex environmental situation (significant emissions and discharges of pollutants into the atmosphere and water bodies, degradation of soil resources, reduction of soil fertility, areas under forests, diversity of agrarian landscapes and landscapes in general, penalties for environmental offenses), environmental annual growth of enterprises' expenditures on environmental tax, the rates of which more than double the rate of increase of capital and current expenditures for environmental protection [2, p. 52].

The assessment of the level of implementation of environmental responsibility in the practice of management of domestic enterprises was conducted by Grishnova 0 . and Brintseva 0. , based on the analysis of their non-financial reports [8, p. 15]. For this purpose, based on the classification of corporate social initiatives by F. Kotler, N. Lee, a system of evaluation criteria was developed [11, p. 186]. The research was conducted on such types of initiatives as "Socially responsible approaches to doing business", "Corporate social marketing", "Volunteering work for the benefit of the community", because it is in these areas of activity of enterprises (and especially in the first of them) that the most significant environmental initiatives are carried out.

According to the results of our analysis for industrial enterprises, the indicators of the block "Socially responsible approaches to doing business" have become the most reflected in social reports. This testifies to the systematic activity of economic entities in the environmental sphere, the introduction of "environmental approaches" to conducting business in the production activity. Companies pay much less attention to "Volunteer work for the benefit of the community" and "Corporate social marketing". However, these components are a promising area for improving the efficiency of environmental projects, especially for agricultural enterprises [1, p. 27]. After all, rural communities, rural areas of their location and end consumers are important stakeholders in all types of agricultural activities.

One of the most difficult tasks of realizing the environmental responsibility of business entities in the agrarian sphere is to maintain a balance between the needs of their development and the need to improve its environmental impact. The basic principles of environmental responsibility of agrarian and industrial enterprises should be as follows:

1. Ensuring ecological safety of food products and technological processes of its production should be based on national laws and standards, international environmental standards and requirements, own standards and regulations of the enterprise and requirements of consumers and other stakeholders.

2. To carry out careful accounting, monitoring and classification of sources of environmental impact, composition and volume of solid and liquid wastes, emissions into the atmosphere as a necessary condition for improvement of environmental protection of enterprises, planning and implementation of programs and decisions aimed at improving the quality of the environment and ecology food safety.

3. To apply modern technologies, the latest scientific developments, knowledge and experience of employees for efficient use of human labor, energy and raw materials resources, reduction of the level of waste of production and consumption in production of products, ecological expertise of new projects and implementations.

4. To educate employees of agrarian sphere enterprises to work in the system of environmental protection, to constantly improve the system of ecological management, to create conditions for public information on the results of environmental responsibility of economic entities to any interested parties.

5. Consistently develop a system of own environmental standards, regularly summarize and disseminate experience of environmental activities, together with local authorities, institutes of civil society in rural areas to participate in the development and implementation of environmental projects, promoting training in healthy lifestyle programs.

The implementation of these principles will help to promote the environmental component of social responsibility of economic entities in the agrarian sphere in the practice of their activities and development management on a continuous basis. The International Organization for Standardization (ISO) has developed standards that help organizations take a proactive approach to environmental 
issues [6, p. 86]. This is a series of ISO 14000 standards for environmental management.

The main document of the series of standards is ISO 14001 "Specification and guidance on the use of environmental management systems". The ISO 14001 standard can be used by companies and businesses in different industries and activities and can be adapted to local requirements and conditions. Certification of environmental management according to the world standards ISO 14000 in Ukraine is not well developed. Today it is not even about hundreds of Ukrainian companies that have received the relevant documents.

Another important point in shaping the environmental responsibility of agrarian sphere businesses is that it must be relevant to the scale of their environmental impact created by their activities, products and services. Environmental responsibility of agrarian and industrial enterprises should be enshrined in the form of a document that is communicated to all employees of the organization and is accessible to the public, approved by them [16, p. 167]. This document should set out the principles of environmental policy of agrarian business entities, their industries and territories of accommodation in accordance with environmental standards, consistent with the mechanisms of continuous improvement of the environmental management system and the prevention of environmental pollution, greening of agricultural production and food production.

Some countries have made the production of agricultural and food products from GMOs equal to state terrorism and banned its production and import, in particular, Russia in 2015. However, the strictness of the laws is limited by the obligation to enforce them. For example, the well-known Monsanto agricultural corporation, thanks to the monopolization of the GM seed market, brought its capitalization to $\$ 44.0$ billion. At the same time, in the last 5 years, the corporation's revenues have grown by $18.0 \%$ annually, and the return on equity has been $12.0 \%$. Meanwhile, crippling agreements on the conditions of use of GMO-seeds, its gradual adaptation to diseases, inability to re-use lead to bankruptcy of farmers and their suicides. Yes, in India because of this during the late 90's of the twentieth century - in 2008 died 150,000 farmers. This testifies to the loss of economic autono- my of farms, the sovereignty of rural areas, regions and entire countries.

Another danger of using GMOs is the loss of biodiversity. Over the past 100 years, over 93\% of crops have been lost in the United States. Instead of hundreds and thousands of them, tens of identical copies remain in the world [12, p. 12]. As a result of the unauthorized or authorized penetration of plants with GMOs, "accidental crossing" (according to the terminology of Monsanto agrarian corporation) occurs, the infection and degeneration of traditional ones in many countries.

However, it is the diversity of crops that is the biological basis of agricultural activity. Plant-borne epidemics spread much more quickly if they are opposed to 2-5 varieties, rather than 100-200, as was the case before. According to $\mathrm{K}$. Fowler, a well-known biodiversity advocate, the consequences of using GMOs are the risks of starvation and the aggravation of food problems in the future. Biodiversity is not just about food. This is also the economic way, material and spiritual culture, lifestyle of the rural population.

When a consumer gives gastronomic preferences to one variety or another, understands and appreciates it, he finances the traditional way of life of producers, which is oriented to its preservation and distribution, national and cultural identity of rural territories of different regions. On the contrary, large agrarian holdings, companies and corporations, unifying varieties, technologies, using GMOs, destroy them [17, p. 14].

So, after the rise in world prices for soybeans in Paraguay, agricultural land was purchased under crops of GM soybeans and other crops. As a result, over $70.0 \%$ of the country's agricultural land became foreign-owned and only $2.0 \%$ of the local rich. The villagers were forced to leave their homes in large numbers and move to cities in search of work and accommodation. It was a devastating first devastating blow to local communities and rural areas. The next one is the contamination of rural areas with herbicides and pesticides by those who do not live and bear no social responsibility.

Therefore, GM crops, hybrids dependent on herbicides so that without them the production of agricultural products on this basis is not economically feasible. However, despite the advertisement of the natural recycling of the most used Roundup, only $2.0 \%$ of its mass 
fraction is completely decomposed in the soil. In addition, the plants themselves are endowed with species-specific protein toxins or insecticides that are capable of neutralizing the biological organisms (insects, etc.) that threaten them. Toxins are also thought to be harmless to humans and soils, and instead contribute to increased yields and competitiveness of agricultural production.

However, according to research, the contamination of the natural environment occurs in at least three ways: through the root residues of plants, wind diversity of pollen, crop residues [15, p. 62]. What a consequence, natural biological ameliorants of the environment suffer - earthworms, ladybugs and others. The cost-effectiveness, which is understood as the undeniable advantage of GM technology, is also unconvincing. Thus, after 5 years genetically modified maize loses its advantages over pests and parasites, and the cost of growing it, for example, on US farms, increases, on average, by $\$ 160 /$ ha.

In the US, the use of herbicides and pesticides has increased by $26.0 \%$ in recent years due to the adaptability of the pests and diseases of the plants weed to them. Therefore, a GM strategy that is not regarded as directed against or against someone or the health of the population, but as a marketing strategy for the monopolization of the global food market is not effective and necessary in the long term. It is, in essence, contrary to the principles of sustainable development and social responsibility to future generations.

For example, according to official statistics, of the total volume of milk produced by dairies, $26.0 \%$ is raw material of the highest quality [4, p. 128]. However, some experts disagree with the official figures, who believe that the share of top-grade milk in Ukraine is less than $3.0 \%$ and that the WTO-compliant milk is absent at all. About $20.0 \%$ of milk falls under WTO standards only as feed material.

In addition, according to market participants, milk that meets the requirements of the highest quality in Ukraine, in the European Union, where the determination of milk grade is made by acidity, degree of purity, bacterial contamination and content of somatic cells, is not accepted for processing at all. For Ukraine, the traditional indicator of milk quality, at which its price is determined, is fat content [5, p. 212]. While other, espe- cially important biologically active components - proteins, carbohydrates, lactose, minerals, vitamins, trace elements, products with the content of which are highly valued in the world market, are not considered.

Also, agricultural enterprises in Ukraine are very differentiated by size, in particular, by the size of the land area - out of 22 of them, more than $50.0 \%$ are enterprises with an area of agricultural land up to 50 hectares, incl. with an area of agricultural land up to 5 hectares, the share of enterprises is more than $10.0 \%$ of their total number. It is clear that small businesses cannot generate sufficient quantities of raw material that may be of interest to processors.

And harvesting cooperatives in Ukraine have not yet or not been properly developed. Thus, Ukrainians do not consume enough apples not because they are not grown well, but because there is no proper harvesting system [22, p. 73]. One wholesale market "Shuvar" in Lviv and several others in Kherson region and the rest of Ukraine are not able to do this. That is why supermarkets sell more apples imported from abroad than domestic ones. Trading networks are better off dealing with a well-established supply system than dealing with rural procurement themselves.

Conclusions. Advanced agrarian business entities are increasingly paying attention to reducing the negative impact of their activities on the environment. The following initiatives in the area of environmental responsibility are most widespread: reduction of energy and resource intensity of production; increasing the amount of waste used or disposed of by the enterprise; development and implementation of strategic programs of environmental activities, first of all reclamation; implementation of international standards of environmental responsibility; environmental monitoring of technology, agricultural raw materials and food, and others. This testifies to the gradual spread of the values of the environmental component in the system of social responsibility of domestic enterprises of the agricultural sector of the economy. However, even at the leading domestic agricultural enterprises, its level does not reach international standards. It needs further development, especially at the level of large agrarian holdings and transnational agricultural corporations. 


\section{Список бібліографічних посилань}

1. Banerjee, Subhabrata Bobby. Corporate social responsibility: the good, the bad and the ugly. Edward Elgar Cheltenham, UK, Northampton, MA, USA. 2007. 153 p.

2. Ignatenko M. M., Marmul L. O. Production-ecological and socio-economic prospects of reproduction and use of bioenergy potential of agrarian enterprises. Science and practice: an innovative approach: Collection of scientific articles. Les Editions L'Originale, Paris, France, 2017. C. 50-54.

3. Ignatenko M. M., Marmul L. O., Ushakov D. S., Kuchyn S. $P$. Transformation of approaches to determine influence factors in the economic development models. International Journal of Economics \& Business Administration, Vol. VII, Issue 2. 2019. Pp. 290-301.

4. Ignatenko M. M., Novak N. P. Development of regional programs for the development of agrarian enterprises with organic production on the basis of the European and international experience. Baltic Journal of Economic Studies. 2018. Vol. 4 (4). C. 126-131.

5. Marmul L., Krukovskaya E. Certification of agrarian enterprises-producers of organic products in order to enter European markets. Baltic Journal of Economic Studies. 2018. Vol. 4(4). C. 209-216.

6. Porter M. E., Cramer M. R. Strategy and Sosiety: The Link Between Competitive Advantage and Corporate Social Responsibility. Harvard Business Review. 2006. December. pp. 78-92.

7. Безус Р. М., Антонюк Г. Я. Ринок органічної продукції в Україні: проблеми та перспективи. Економіка АПК. 2011. № 6. C. 47-52.

8. Грішнова О., Брінцева О. Впровадження екологічної відповідальності в практику менеджменту вітчизняних підприємств. Вісник Київського національного університету ім. Тараса Шевченка: Економіка. 2013. № 10 (151). С. 12-18.

9. Єрмоленко А. М. Соціальна етика та екологія. Гідність людини - шанування природи : монографія. Київ : Лібpa, 2010. 416 c.

10. Князєва Т. В. Розвиток системи екологічного менеджменту на підприємстві: основні теоретичні положення. Теоретичні і практичні аспекти економіки та інтелектуальної власності. 2014. Вип. 1(1). С. 391-396.

11. Котлер Ф., Лі Н. Корпоративна соціальна відповідальність. Як зробити якомога більше добра для вашої компанії та суспільства / пер. 3 англ. С. Яринич. Київ : Стандарт, 2005. 302 c.

12. Лупенко Ю. О., Захарчук О. В. Інвестиційне забезпечення інноваційного розвитку сільського господарства України. Економіка АПК. 2018. № 11. С. 9-18.

13. Малиновський A. С. Порівняльний аналіз деяких прогнозних показників розвитку сільського господарства регіону. Вісник ЖНАЕУ. 2016. № 1 (54), т. 2. С. 81-87.

14. Прутська О. О., Ходаківська О. В. Органічне сільське господарство в США: реалії та перспективи для України. Економіка АПК. 2011. № 12. С. 142-151.

15. Резнікова О. С. Класифікація підходів до прийняття управлінських рішень у контролінгу. Вісник Одеського національного університету. Серія: Економіка. 2013. Т. 18, вип. 3(3). С. 61-63.

16. Римар І. А. Соціальні інвестиції як форма соціальної відповідальності підприємства. Актуальні проблеми економіки. 2012. № 9. С. 165-168.

17. Романюк I. А. Особливості відтворювального процесу в аграрному секторі. Агросвіт. 2016. № 11. С. 12-15.

18. Саблук П. Т. Наукові агроекономічні дослідження в інтересах активізації росту АПВ і сільських територій. Економіка АПК. 2017. № 5. С. 19-23.

19. Сохнич А. Я., Якимчук А. Ю., Казаченко Л. М. Управління земельними ресурсами: оцінювання кредитоспроможності інноваційних проектів. Вісник економічної науки України. 2019. № 1 (36). С. 128-132.

20. Туниця Ю. Ю., Семенюк Е. П., Туниця Т. Ю. Екологізація економіки: теоретико-методологічний аспект. Економічна теорія. 2011. № 2. С. 5-15.

\section{References}

1. Banerjee, Subhabrata Bobby (2007). Corporate social responsibility: the good, the bad and the ugly. Edward Elgar Cheltenham, UK, Northampton, MA, USA [In English].

2. Ignatenko, M.M. \& Marmul, L.O. (2017). Productionecological and socio-economic prospects of reproduction and use of bioenergy potential of agrarian enterprises. Science and practice: an innovative approach: Collection of scientific articles, pp. 50-54. Paris: Les Editions L'Originale. [In English].

3. Ignatenko, M.M., Marmul, L.O., Ushakov, D.S., \& Kuchyn, S.P. (2019). Transformation of approaches to determine influence factors in the economic development models. International Journal of Economics \& Business Administration, VII (2), pp. 290-301 [In English].

4. Ignatenko, M.M. \& Novak, N.R. (2018). Development of regional programs for the development of agrarian enterprises with organic production on the basis of the European and international experience. Baltic Journal of Economic Studies, 4 (4), pp. 126-131 [In English].

5. Marmul, L. \& Krukovskaya, E. (2018). Certification of agrarian enterprises-producers of organic products in order to enter European markets. Baltic Journal of Economic Studies, 4 (4), pp. 209-216 [In English].

6. Porter, M.E. \& Cramer, M.R. (2006). Strategy and society: the link between competitive advantage and corporate social responsibility. Harvard Business Review, December, pp. 7892 [In English].

7. Bezus, R.M. \& Antoniuk, H.Ya. (2011). Rynok orhanichnoi produktsii $\vee$ Ukraini: problemy ta perspektyvy [Organic produce market in Ukraine: problems and prospects]. Ekonomika APK, 6, pp. 47-52 [In Ukrainian].

8. Hrishnova, O. \& Brintseva, O. (2013). Vprovadzhennya ekolohichnoyi vidpovidal'nosti $v$ praktyku menedzhmentu vitchyznyanykh pidpryyemstv [Introduction of environmental responsibility in the practice of management of domestic enterprises]. Visnyk Kyyivskoho natsionalnoho universytetu im. T. Shevchenka: Ekonomika, 10 (151), pp. 12-18 [In Ukrainian].

9. Yermolenko, A.M. (2010). Sotsialna etyka ta ekolohiya. Hidnist lyudyny - shanuvannya pryrody: monohrafiya [Social ethics and ecology. dignity of man - reverence for nature: monograph]. Kyiv: Libra [In Ukrainian].

10. Knyazyeva, T.V. (2014). Rozvytok systemy ekolohichnoho menedzhmentu na pidpryyemstvi: osnovni teoretychn polozhennya [Development of environmental management system at the enterprise: basic theoretical propositions]. Teoretychni i praktychni aspekty ekonomiky ta intelektualnoyi vlasnosti, 1 (1), pp. 391-396 [In Ukrainian].

11. Kotler, F. \& Li, N. (2005). Korporatyvna sotsialna vidpovidalnist. Yak zrobyty yakomoha bilshe dobra dlya vashoyi kompaniyi ta suspilstva [Corporate social responsibility. How to do the best possible for your company and society]. Kyiv: Standart [In Ukrainian].

12. Lupenko, Yu.O. \& Zakharchuk, O.V. (2018). Investytsiyne zabezpechennya innovatsiynoho rozvytku silskoho hospodarstva Ukrayiny [Investment support of innovative development of agriculture of Ukraine]. Ekonomika APK, 11, pp. 9-18 [In Ukrainian].

13. Malynovskyi, A.S. (2016). Porivnialnyi analiz deiakykh prohnoznykh pokaznykiv rozvytku silskoho hospodarstva rehionu [Comparative analysis of some of the agricultural indicators in the region]. Visnyk ZHNAEU, 1 (54), pp. 81-87 [In Ukrainian].

14. Prutska, O.O. \& Khodakivska, O.V. (2011). Orhanichne silske hospodarstvo $\vee$ SShA: realii ta perspektyvy dlia Ukrainy [Organic farming in the United States: realities and prospects for Ukraine]. Ekonomika APK, 12, pp. 142-151 [In Ukrainian].

15. Reznikova, O.S. (2013). Klasyfikatsiya pidkhodiv do pryynyattya upravlinskykh rishen u kontrolinhu [Classification of approaches to management decision-making in controlling]. Visnyk Odeskoho natsionalnoho universytetu. Ekonomika, Vol. 18, 3 (3), pp. 61-63 [In Ukrainian].

16. Rymar, I.A. (2012). Sotsialni investytsiyi yak forma sotsialnoyi vidpovidalnosti pidpryyemstva [Social investment as a form of corporate social responsibility]. Aktualni problemy ekonomiky, 9, pp. 165-168 [In Ukrainian]. 
21. Хвесик М. А., Бистряков І. К. Інноваційні домінанти сталого розвитку України. Проблеми інноваційноінвестиційного розвитку. Серія : Економіка та менеджмент. 2016. № 9. С. 182-193.

22. Шпикуляк О. Г., Малік М. Й. Інституціональний аналіз розвитку підприємництва в аграрному секторі економіки: методичний аспект. Економіка АПК. 2019. № 6. С. 73-82.
17. Romanyuk, I.A. (2016). Osoblyvosti vidtvoryuvalnoho protsesu $\mathrm{v}$ ahrarnomu sektori [Features of the reproduction process in the agricultural sector]. Ahrosvit, 11, pp. 12-15 [In Ukrainian].

18. Sabluk, P.T. (2017). Naukovi ahroekonomichni doslidzhennya $v$ interesakh aktyvizatsiyi rostu APV i silskykh terytoriy [Scientific agro-economic research in the interest of accelerating the growth of IAP and rural areas]. Ekonomika APK, 5, pp. 19-23 [In Ukrainian].

19. Sokhnych, A.Ya., Yakymchuk, A.Yu., \& Kazachenko, L.M. (2019). Upravlinnia zemelnymy resursamy: otsinyuvannya kredytospromozhnosti innovatsiinykh proektiv [Land management: evaluating the creditworthiness of innovative projects]. Visnyk ekonomichnoi nauky Ukrayiny, 1 (36), pp. 128-132 [In Ukrainian].

20. Tunytsya, Yu.Yu., Semenyuk, E.P. \& Tunytsya, T.Yu. (2011). Ekolohizatsiya ekonomiky: teoretyko-metodolohichnyy aspect [Greening the economy: a theoretical and methodological aspect]. Ekonomichna teoriya, 2, pp. 5-15 [In Ukrainian].

21. Khvesyk, M.A. \& Bystryakov, I.K. (2016). Innovatsiyni dominanty staloho rozvytku Ukrayiny [Innovative dominants of sustainable development of Ukraine]. Problemy innovatsiynoinvestytsiynoho rozvytku. Seriya: Ekonomika ta menedzhment, 9, pp. 182-193 [In Ukrainian].

22. Shpykulyak, O.H. \& Malik, M.Y. (2019). Instytutsionalnyy analiz rozvytku pidpryyemnytstva $v$ ahrarnomu sektori ekonomiky: metodychnyy aspect [Institutional analysis of entrepreneurship development in agricultural sector of economy: methodical aspect]. Ekonomika APK, 6, pp. 73 [In Ukrainian]

Ігнатенко М.М. Екологічні складники та інструменти здійснення соціальної відповідальності підприємствами агробізнесу

Мета статmі - обгрунтувати вибір і застосування інструментів та засобів посилення екологічної складової у структурі соціальної відповідальності суб'єктів агробізнесу, у тому числі на засадах виваженого використання генно-модифікованих організмів (ГМО), розвитку виробництва органічної продукції, що пов'язано із продовольчою безпекою загалом.

Методика дослідження. Методологічну основу дослідження становлять положення сучасної економічної теорії, економіки підприємств агробізнесу, концепції соціальної відповідальності, раціонального природокористування й сталого розвитку. Використано загальнонаукові методи наукового пізнання - діалектичний, історичний, монографічний (при визначенні тенденцій розвитку сільськогосподарського виробництва, природокористування, його екології й соціальної відповідальності за них); системно-структурного аналізу й синтезу (під час аналізу й структуризації екологічних проблем, напрацюванні на цій основі єдиної стратегії і тактики їх вирішення засобами соціальної відповідальності), а також статистико-економічних і соціально-екологічних досліджень (при встановленні кількісних показників та індикаторів природокористування й екології у процесі аграрного виробництва, встановленні причинно-наслідкових зв'язків між ними та їх вимірювання), експертних оцінок, соціологічного опитування (при обгрунтуванні перспектив вирішення екологічних проблем у межах концепції соціальної відповідальності за відсутності статистичних джерел для розрахунків та прогнозів).

Результати дослідження. Виявлено особливості, проблеми та здійснено оцінку екологічної ефективності й екологізації аграрного виробництва, у тому числі використання ГМО та його наслідків. Обгрунтовано необхідність соціальної відповідальності підприємств агробізнесу за екологічні наслідки діяльності. Визначено ії функції, принципи, інструменти й механізми у вирішенні екологічних проблем. Встановлено, що провідні суб'єкти господарювання агросфери приділяють все більше уваги зменшенню негативного впливу своєї діяльності на довкілля. Підкреслено цінність таких ініціатив у сфері екологічної відповідальності, результатом чого стає: зниження енерго- та ресурсоємності виробництва; збільшення обсягів відходів, використаних або знешкоджених підприємством; розробка та реалізація стратегічних програм екологічної діяльності, насамперед меліорацій; впровадження міжнародних стандартів екологічної відповідальності; екологічний моніторинг технологій, сільськогосподарської сировини і продовольства та ін. Тобто відбувається поступове поширення пріоритетів екологічної складової у системі соціальної відповідальності вітчизняних підприємств аграрної сфери економіки. Однак їі рівень навіть у провідних вітчизняних аграрних підприємствах не досягає міжнародних стандартів і потребує подальшого розвитку, особливо на рівні великих агрохолдингів та транснаціональних аграрних корпорацій.

Елементи наукової новизни. Вперше у межах концепції соціальної відповідальності здійснено уточнення екологічної складової та визначено засоби їі посилення у вигляді виваженого використання ГмО, органічного виробництва, впровадження екологічно орієнтованого менеджменту. При цьому підкреслюється важливість використання концепції саме соціальної відповідальності. Адже тільки вона забезпечує усвідомлену екологізацію сільського господарства на рівні всіх учасників виробничого процесу.

Практична значущість. Отримані результати та висновки можуть бути використані при підготовці та перепідготовці керівних кадрів, фахівців, власників підприємств агробізнесу, у господарській діяльності. Також доцільно впроваджувати їх у роботу регіональних органів влади, сільських громад, громадських організацій. Табл.: 2. Бібліогр.: 22.

Ключові слова: аграрні підприємства; екологічні проблеми; органічне виробництво; генно-модифіковані організми; соціальна відповідальність; інструменти; управління.

Ігнатенко Микола Миколайович - доктор економічних наук, доцент, завідувач кафедри економіки, Державний вищий навчальний заклад «Переяслав-Хмельницький державний педагогічний університет імені Григорія Сковороди» (м. Переяслав-Хмельницький, вул. Сухомлинського, 30)

E-mail: professorignatenko@ukr.net

ORCID iD https://orcid.org/0000-0002-5713-7951 
Игнатенко Н.Н. Экологические составляющие и инструменты осуществления социальной ответственности предприятиями агробизнеса

Цель статьи - обосновать выбор и использование инструментов и средств усиления экологической составляющей в структуре социальной ответственности субъектов агробизнеса, в том числе на основе взвешенного использования генно-модифицированных организмов (ГМО), развития производства органической продукции, что связано с продовольственной безопасностью в целом.

Методика исследования. Методологическую основу исследования составляют положения современной экономической теории, экономики предприятий агробизнеса, концепции социальной ответственности, рационального природопользования и устойчивого развития. Использованы общенаучные методы научного познания - диалектический, исторический, монографический (при определении тенденций развития сельскохозяйственного производства, природопользования, его экологии и социальной ответственности за них); системно-структурного анализа и синтеза (в процессе анализа и структуризации экологических проблем, наработке на этой основе единой стратегии и тактики их решения средствами социальной ответственности), а также статистико-экономических и социально-экологических исследований (при установлении количественных показателей и индикаторов природопользования и экологии в процессе аграрного производства, установлении причинно-следственных связей между ними и их измерения), экспертных оценок, социологического опроса (при обосновании перспектив решения экологических проблем в пределах концепции социальной ответственности при отсутстви статистических источников для расчетов и прогнозов).

Результаты исследования. Выявлены особенности, проблемы и осуществлена оценка экологической эффективности и экологизации аграрного производства, в том числе использования Гмо и его последствий. Обоснована необходимость соци альной ответственности предприятий агробизнеса за экологические последствия деятельности. Определены ее функции, принципы, инструменты и механизмы в решении экологических проблем. Установлено, что ведущие субъекты хозяйствования агросферы уделяют все больше внимания уменьшению негативного влияния своей деятельности на окружающую среду. Подчеркнута ченность таких инициатив в сфере экологической ответственности, результатом чего становится: снижение энерго- и ресурсоемкости производства; увеличение объемов отходов, использованных или обезвреженных предприятием; разработка и реализация стратегических программ экологической деятельности, прежде всего мелиораций; внедрение международных стандартов экологической ответственности; экологический мониторинг технологий, сельскохозяйственного сырья и продовольствия и др. То есть происходит постепенное распространение приоритетов экологической составляющей в системе социальной ответственности отечественных предприятий аграрной сферы экономики. Однако ее уровень даже у ведущих аграрных предприятиях не достигает международных стандартов и требует дальнейшего развития, особенно на уровне крупных агрохолдингов и транснациональных аграрных корпораций.

Элементы научной новизны. Впервые в пределах концепции социальной ответственности осуществлено уточнение экологической составляющей и определены способы ее усиления в виде взвешенного использования ГмО, органического производства, внедрения экологически ориентированного менеджмента. При этом подчеркивается важность использования концепции именно социальной ответственности. Ведь только она обеспечивает осознанную экологизацию сельского хозяйства на уровне всех участников производственного процесса.

Практическая значимость. Полученные результаты и выводы могут быть использованы при подготовке и переподготовке руководящих кадров, специалистов, владельцев предприятий агробизнеса, в хозяйственной деятельности. Также целесообразно внедрять их в работу региональных органов власти, сельских общин, общественных организаций. Табл.: 2. Библиогр.: 22.

Ключевые слова: аграрные предприятия; экологические проблемы; органическое производство; генномодифицированные организмы; социальная ответственность; инструменты; управление.

Игнатенко Николай Николаевич - доктор экономических наук, доцент, заведующий кафедрой экономики, Государственное высшее учебное заведение «Переяслав-Хмельницкий государственный педагогический университет имени Григория Сковороды» (г. Переяслав-Хмельницкий, ул. Сухомлинского, 30)

E-mail: professorignatenko@ukr.net

ORCID iD https://orcid.org/0000-0002-5713-7951

The article has been received 02.09.2019

Revision: 12.09.2019

Бібліографічний опис для цитування:

Ihnatenko M. M. Ecological components and instruments of implementation of social responsibility to agrobusiness enterprises. Економіка АПК. 2019. № 9. С. 52 - 61.

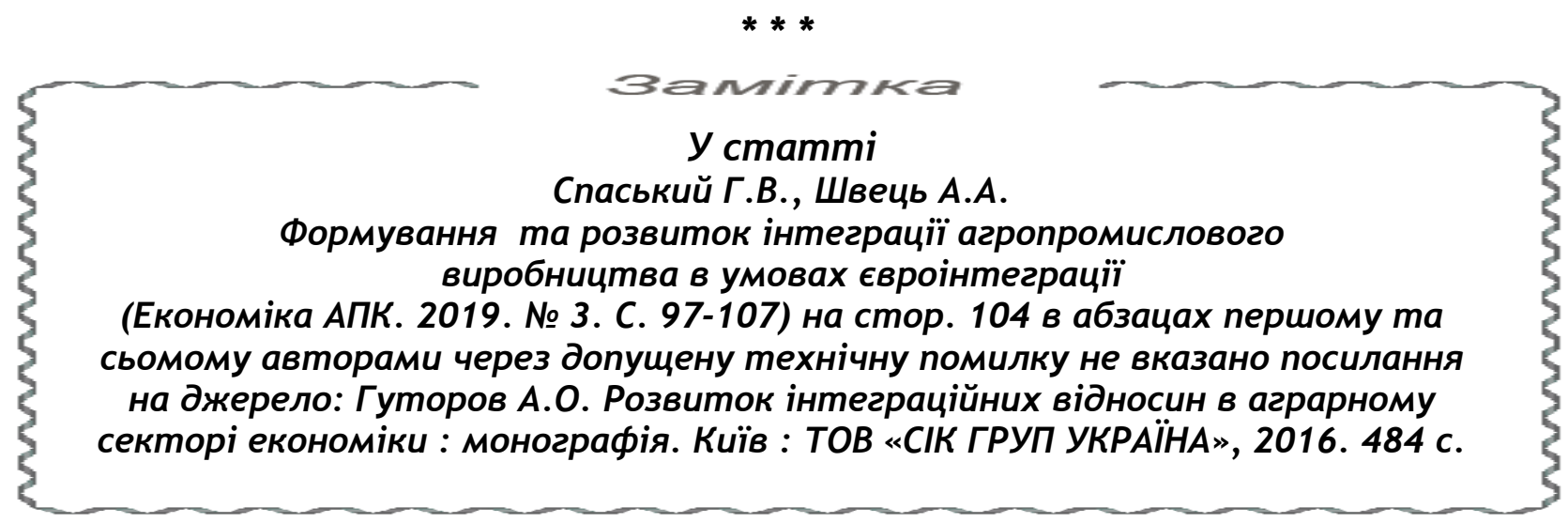

